\title{
Seeds characters, pollen fertility and flavonoids of ten Brassicaceae collected near a kilns thermal power plant for air pollution bioindication
}

\author{
MITRA NOORI ${ }^{1, \boldsymbol{\nu}}$, ZAHRA BAGHAEIFAR $^{2}$, ABDOLKARIM CHEHREGANI $^{3}$, FARZANEH FARAKI $^{2}$ \\ ${ }^{1}$ Department of Biology, Faculty of Science, Arak University, Arak 38156-8-8349-Iran. Tel./fax.: +98-86-34173406, ”email: m-noori@araku.ac.ir \\ ${ }^{2}$ Department of Biology, Hamadan Payame Noor University, Hamadan 65199-9951, Iran \\ ${ }^{3}$ Department of Biology, Faculty of Science, Bu-Ali Sina University, Hamadan 6517838695, Iran
}

Manuscript received: 9 April 2018. Revision accepted: 13 May 2018

\begin{abstract}
Noori M, Baghaeifar Z, Chehregani A, Faraki F. 2018. Seeds characters, pollen fertility and flavonoids of ten Brassicaceae collected near a kilns thermal power plant for air pollution bioindication. Nusantara Bioscience 10: 96-104. Shazand Steam Power Plant located on North-East of Shazand, Iran began to work from 2000. The power plant necessity fuel is natural gas and mostly heavy fuel oil. The most pollutant of power plant is sulfur compounds in addition to nitric and carbon mono oxide. Because environmental pollutants influence plant fertility and chemical compounds, therefore this study was done on ten wild Brassicaceae (Alyssum linifolium var. linifolium, Alyssum longistylum, Alyssum marginatum, Choriospora persica, Clypeola lappacea, Conringia perfoliata, Descurainia sophia, Goldbachia laevigata, Isatis kotschyana and Neslia apiculata) taxa collected from the thermal power plant area for bioindication of regional air pollution comparing to controls collected $40 \mathrm{~km}$ away from the power plant. Brassicaceae members are important for their ecological, pastoral, medicinal and edible points. Seed width and length max. and their ratio and abnormal seed percentage were calculated. Pollen abnormality and sterility percentages determined using Muntezing's acetocarmine and light microscopy. Also, their pollen flavonoids were semi-quantitatively assessed using two-dimensional paper and thin layer chromatography. Results showed seeds health and their dimensions reduction in polluted samples in comparison with controls. In C. lappacea significant differences of seed and pollen abnormality and pollen sterility percentages, morin and kaempferol concentrations, between control and polluted samples were observed $(P \leq 0.05)$. Also, number and kind of pollen flavonoid changes especially increasing flavonoid contents were observed in polluted plants comparing to control. Studying seed and pollen characters can be used as air quality bioindicators.
\end{abstract}

Keywords: Air pollution, bioindicator, Brassicaceae, flavonoids, pollen, power plant

\section{INTRODUCTION}

Thermal power plants are designed in a variety of fashions depending on the available fuel, mostly natural gas and heavy fuel oil. Depending on the fired fuel, emission of thermal power plants is sulphuric and nitric oxides. Sulfur oxides constitute the most common pollution when burning heavy fuel oil (Noori et al. 2014). By the reason Brassicaceae taxa importance from ecological, pastoral, medicinal and edible points, this study was done on 10 collected Brassicaceae taxa from the area and their controls.

Using plants for biomonitoring of air and soil quality may turn out to be successful, as they are simple, cheap and fast. They can supplement the classical physicochemical methods. By these types of techniques, the information on the pollutants can be derived from the study of the biological responses of plants to pollution (Malayeri et al. 2007). Many authors studied on reactions of plants to air pollutants, and those species suitable as plant bioindicators (Gottardini et al. 2004). Bosac et al. (1994) investigated the impact of $\mathrm{O}_{3}$ and $\mathrm{SO}_{2}$ on reproductive development of oil seed rape (Brassica napus), pollen germination. Pollen as a biologic allergen is a sensitive bioindicator of atmospheric pollution and provides particularly original and interesting information on the potential adverse effects of pollutants on living organisms (Yosefi et al. 2011). Air pollution affects on growth, development, morphobiometrical and phytochemical pollen grains parameters. Many pollutants have direct impact on the pollen physiology; and indirect impact on its ontogenesis via their effects on plant reproduction. It may be pointed out that this ontogenesis is also subordinated to the other environmental factors (atmospheric and/or edaphic) acting on the producing plants. Of course, pollen does not indicate levels of pollutants, but it measures their biological impact (Gottardini et al. 2004).

Pollen viability and morphology were used for fluoride pollution biomonitoring (Malayeri et al. 2011). Studies on collected pollen from polluted and unpolluted areas have shown contradictory results. Acid rain could affect developmental process of pollen grains. Exine was not formed in some case of plants that treated by different acid solutions (Chehregany et al. 2006). Pollination with $\mathrm{SO}_{2}$ fumigated pollen resulted in reduced seed production and weight (Elke 1990). Low-level $\mathrm{O}_{3}$ and/or $\mathrm{SO}_{2}$ exposure causes a linear decline in soybean yield and high-level exposure caused significant linear reductions of $4-7 \%$ in mass per seed, seed number and weight (Sprugel et al. 1980, Reich and Amundson 1984). Studies on extracts of exposed Quercus rubra, Festuca elatior and Ulmas pumila pollen grains with $\mathrm{CO}, \mathrm{SO}_{2}$ and $\mathrm{NO}_{2}$ using twodimensional thin layer chromatography and SDS-gel electrophoresis (PAGE) methods showed changing amino 
acids and molecular weight profiles. Also, antigenic changes were observed in contaminated pollen comparing to control using double immune-diffusion method (Ruffin et al. 1986). Air pollution effects on structures, proteins, and allergenicity of pollen grains using SDS-PAGE method showed decreasing protein content in all of polluted samples in response to air pollution. (Majd et al. 2004). Changing pollen protein profiles and appearing some new bands in DEP (diesel exhaust particles)-exposed pollen grains were observed in polluted Lilium martagon pollen extract comparing to control (Chehregany and Kouhkan 2008).

Anthocyanins were as an indicator for plant responses to environmental stress (Chalker-Scot 1999). Polyphenolics were introduced as indicator to different environmental stresses. It shows plant metabolic adaptation with increasing flavonoids content responding to environmental pollution (Rezanezhad and Nasibi 2006). Rezanejad (2012) stated that phenolic compounds function as stress indicators because they accumulate to high levels in many plant tissues in response to a wide range of biotic and abiotic signals. These compounds are involved in pollen development, pollination, pollen germination, and pollen tube growth (Rezanejad 2012). Feucht and Treutter (1999) studied the role of flavan-3-ols in plant defense. They found that flavan-3-ols and other phenolic compounds as unsaturated oil acids protective are reported against free radicals. Also flavanols increase cell membrane protective agents (Feucht and Treutter 1999). Analyzing polluted pollen grain extracts, using HPLC showed increasing flavonoids level in polluted pollen in comparison with control (Rezanejad 2012). Such studies indicated that seeds and pollen grains provide essential information on biological impact of pollutants and they are good candidates for biomonitoring the atmospheric and edaphic pollutions.
In this study effects of Shazand Thermal Power Plant (Iran) pollution on seeds characters, pollen fertility and flavonoids profile in 10 collected Brassicaceae taxa from the Power Plant area (having $\mathrm{SO}_{2}, \mathrm{CO}, \mathrm{NO}$ ) in comparison with control $40 \mathrm{~km}$ away from the power plant (no this pollutant) were investigated. Also about using these characters as air pollution bioindicators is discussed.

\section{MATERIALS AND METHODS}

\section{Collection of plant material, determination, and seed morpho-biometry}

Plant material of ten wild and native Brassicaceae taxa (Alyssum linifolium var. linifolium, Alyssum longistylum, Alyssum marginatum, Choriospora persica, Clypeola lappacea, Conringia perfoliata, Descurainia sophia, Goldbachia laevigata, Isatis kotschyana and Neslia apiculata) were collected (five samples of each taxa) from the Shazand Thermal Power Plant (http://www.mapna.com/en/products/power) area located at NE of Shazand, Markazi Province, Iran and its geographical coordinates are 33० 53' 25" North, 49 9' 43" East (Figure 1) (http://www.maplandia.com/iran/markazi/shazand). Control samples were collected from $40 \mathrm{~km}$ distances of the Power Plant. Herbarium vouchers were prepared. Collected plant identified using available authoritative references (Rechinger 1968; Mobayen 1979; Ghahreman 1976-2008) (Figure 2).

Seed morphobiometrical studies were done using a zoom binocular light microscope. Seed length maximum (SLM), seed width maximum (SWM), seed length max/seed width max (SLM/SWM), seed diameter max (SDM), normal seed\% (NS\%) and abnormal seed\% (AS\%) measured and calculated for 10 plants of each taxon. Round and having kernel seeds were considered normal versus wrinkled, holed and lacked kernel seeds as abnormal.

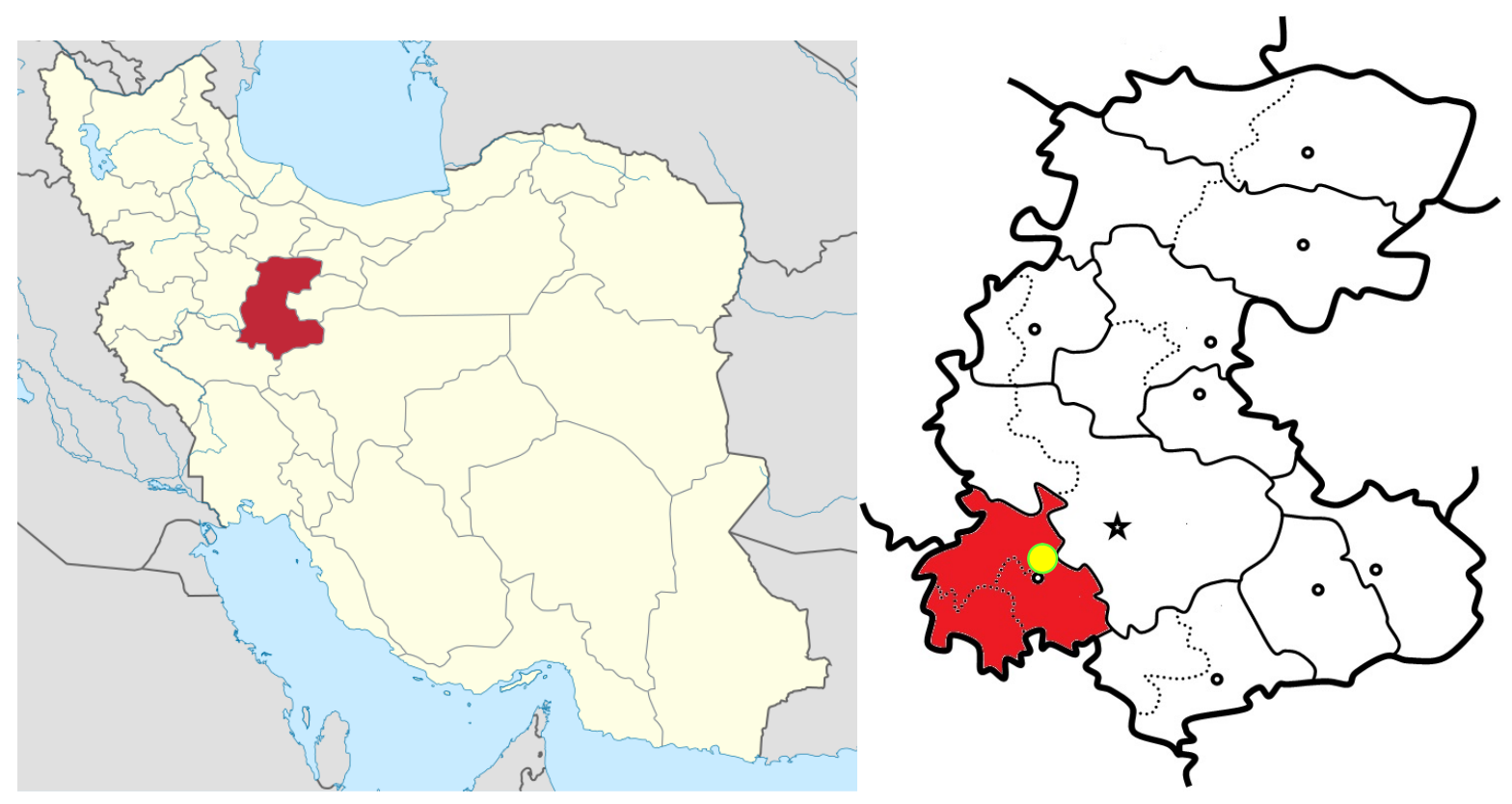

Figure 1. Showing the Shazand Thermal Power Plant area located at NE of Shazand, Markazi Province, Iran 


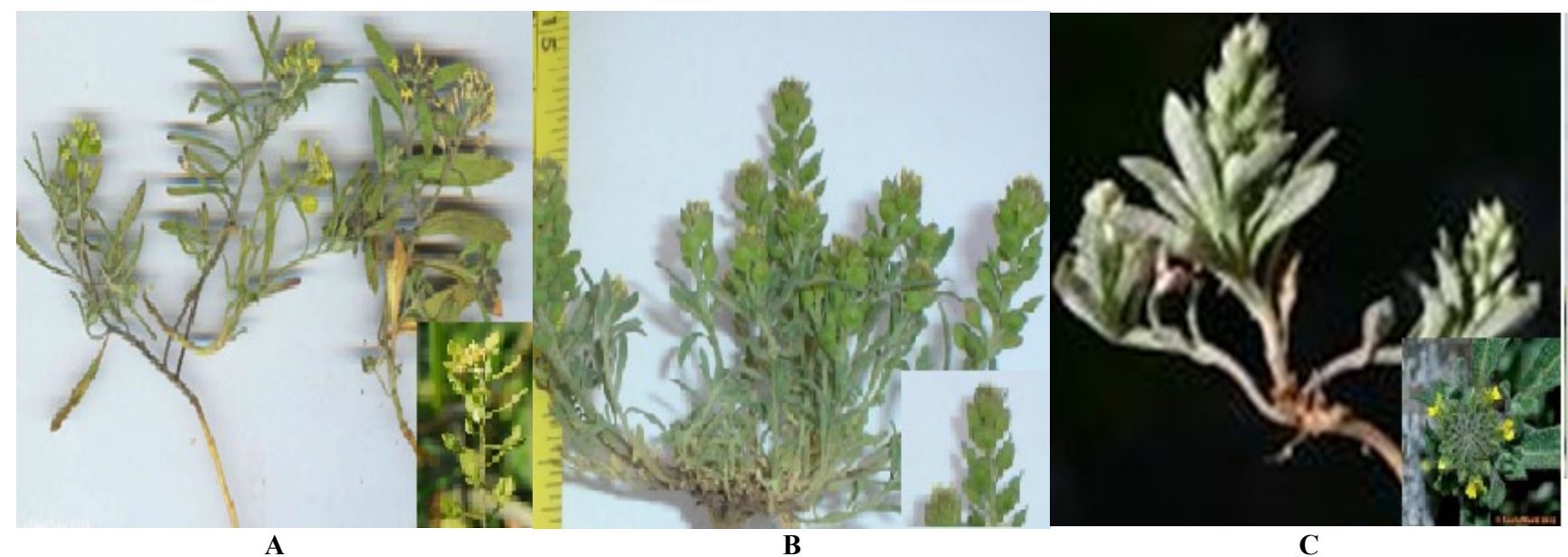

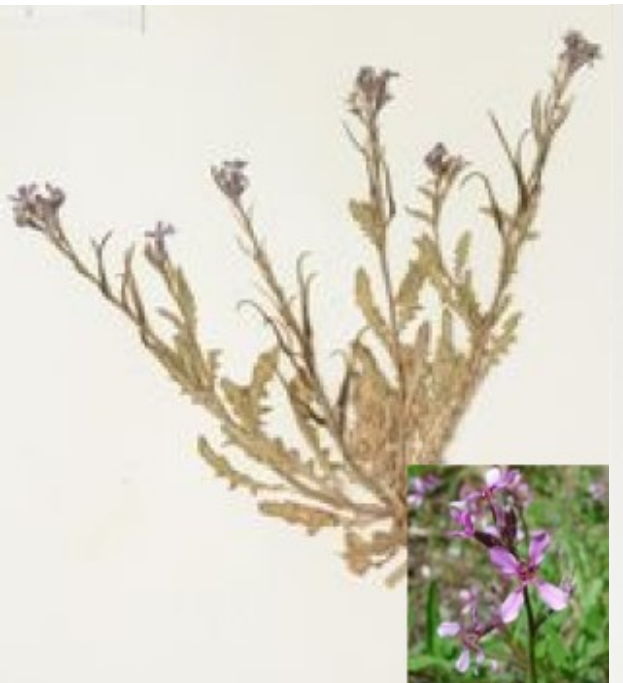

D

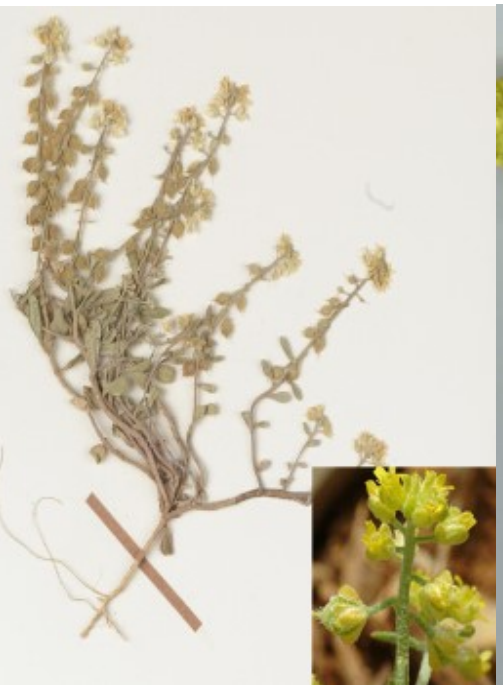

$\mathbf{E}$

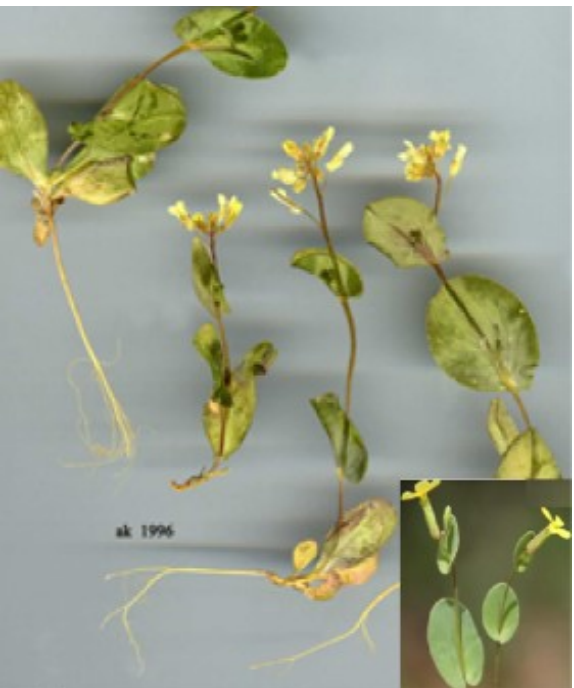

$\mathbf{F}$

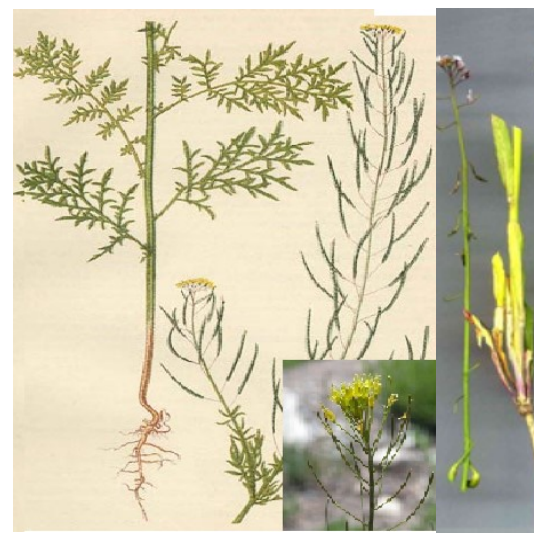

G

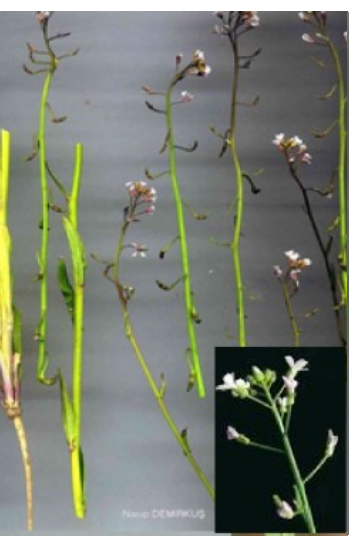

H

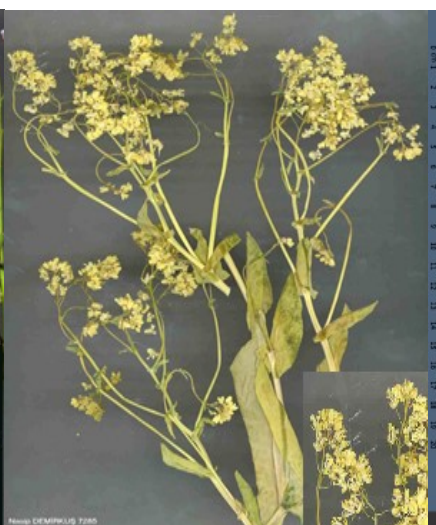

I

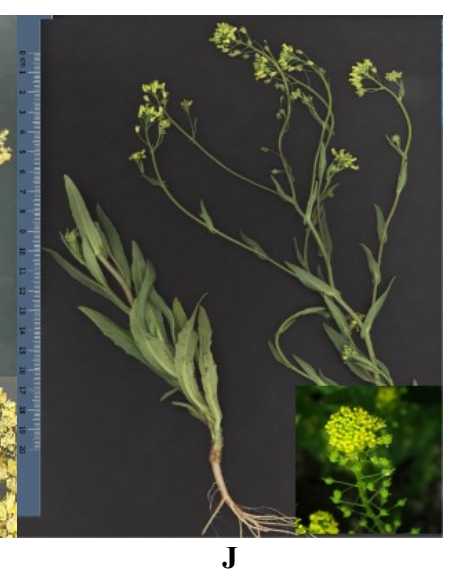

Figure 2. Showing habit of 10 studied Brassicaceae taxa. A. Alyssum linifolium var. linifolium, B. Alyssum longstylum, C. Alyssum marginatum, D. Choriospora persica, E. Clypeola lappacea, F. Conringia perfoliata, G. Descurainia sophia, H. Goldbachia laevigata, I. Isatis kotschyana, J. Neslia apiculata

\section{Preparation and light microscopy of pollen grains}

Flowers of all collected control and polluted samples were fixed in Carnoy's solution (a fixative composed of glacial acetic acid and ethanol 3:1). Pollen grains were studied using Muntezing's acetocarmine method (Noori 2002). Five samples from each species were randomly chosen, and their anthers smashed on a microscopic slide.
Empty anther shells were removed, and one drop of the staining solution was applied to the pollen grains on the respective slide. After uniformly dispersing the pollen and stains, they were covered with a cover slip. 24-48 hours later, the slides were observed by light microscopy (Galen III, Leica, Wetzlar, Germany). Palynological characters such as abnormality and sterility percentages were 
determined for each control and polluted sample. Pollens were categorized into two groups those with round exine and regular shape (normal) and these with wrinkled, shrunk, fragile exine and irregular shape (abnormal). Percentages of stained pollen (fertile) and non stained pollen (sterile) were also scored.

\section{Preparation and extraction of pollen grains}

Pollen grain samples from mature fresh flower anthers were air dried after dissection of the flowers for flavonoids detection and identification. For a comparative analysis of the flavonoids, small extracts of all the accessions were prepared by boiling $200 \mathrm{mg}$ of powdered pollen grain for 2 min in $5 \mathrm{~mL} 70 \%$ ethanol/water. The mixture was cooled and left to extract for $24 \mathrm{~h}$. The extract was filtered, evaporated to dryness by rotary evaporation at $40^{\circ} \mathrm{C}$ and taken up in $2 \mathrm{~mL} 80 \% \mathrm{MeOH} /$ water for analysis by twodimensional paper chromatography (2-D PC) (Noori 2002).

\section{Flavonoid analysis by 2-D PC}

Aliquots of 10 times $2 \mu \mathrm{L}$ of each extract were applied to the corner of a quarter sheet of chromatography paper (Whatman No 1). The chromatograms were developed in the first direction with n-butanol-acetic acid-water=4:1:5 $\mathrm{v} / \mathrm{v}$, upper layer (BAW) and in the second direction with $15 \%$ aqueous acetic acid, with rutin (= quercetin 3-Orutinoside) as standard. After development, the chromatograms were viewed in UV $366 \mathrm{~nm}$ and any dark absorbing and fluorescent spots were marked. $\mathrm{R}_{f}$-values were calculated (Noori et al. 2002).

\section{Methods of identification of the flavonoids}

After obtaining sufficient amounts of purified flavonoids, as in the case of the flavonoids from 10 Brassicaceae taxa pollen, they were identified by means of UV spectroscopy using shift reagents to investigate the substitution patterns of the flavonoids (Mabry et al. 1970; Markham 1982) and by acid hydrolysis to identify the aglycone and sugar moieties. Co-chromatography with standards was also performed where possible. Flavonoid standards available for comparison during the study were apigenin, chrysin, genistein, hesperidin, isorhamnetin, kaempferol, luteolin, morin, myricetin, naringenin, quercetin, rhamnetin, rutin, tricine and vitexin, rutin (ILDIS 1994) from Merck, Darmstadt, Germany; apigenin and luteolin from Sigma, St. Louis, MO, USA; and the others from Fluka-Sigma-Aldrich, Deisenhofen, Germany).

\section{Acid hydrolysis and identification of flavonoid aglycones}

After dissolving a small amount of each purified flavonoid (ca $0.5 \mathrm{mg}$ ) in $0.5 \mathrm{ml}$ of $80 \% \mathrm{MeOH}$ in a test tube, $2 \mathrm{ml}$ of $2 \mathrm{M} \mathrm{HCl}$ were added and the mixture was heated. Then $2 \mathrm{ml}$ of EtOAc were added and thoroughly mixed with the aqueous layer using a Whirley mixer after cooling. The upper EtOAc layer was removed and evaporated to dryness, dissolved in $0.5 \mathrm{ml}$ of $\mathrm{MeOH}$ and applied as spots on thin layer chromatograms (cellulose). The TLC plates were run in three solvents alongside standards to identify the aglycone moiety (Harborne 1998). Then TLC chromatograms were viewed in UV $254 \mathrm{~nm}$ and each spot $\mathrm{R}_{f}$-values and color comparing to standards helped to kind of flavonoids identification.

\section{Data analysis}

Seed morphobiometrical data results were analyzed by EXCEL. Pollen abnormality and sterility percentages were calculated. Pollen grain flavonoids data were scored. Then all of obtained data were analyzed by ANOVA, Duncan, and Tukey tests $(P \leq 0.05)$ using SPSS.

\section{RESULTS AND DISCUSSION}

\section{Results}

Seed morphobiometrical studies results showed seed dimensions, and seed normality percentage had reduction in all of studied taxa except Neslia apiculata species that abnormal seed percentage was higher than in control comparing to polluted (Table 1). Table 2 shows palynological data of polluted samples comparing to control using Muntezing's acetocarmine method. Results showed all of studied control plant pollen grains were elliptic and tricolporate (Figure 3). All of control samples of ten collected Brassicaceae taxa from $10 \mathrm{~km}$ distances of the Shazand Thermal Power Plant area exceptional $G$. laevigata and I. kotschyana showed $100 \%$ fertility in their pollen grains. While, abnormality was observed in all of studied polluted samples. Also their total sterility\% increased. Polluted I. kotschyana had the most abnormal pollen grains $(50.8 \%)$ and maximum sterility (45.5\%). Minimum abnormality pollen grains $(4.9 \%)$ and minimum sterility $(4.92 \%)$ were observed in polluted G. laevigata.

Pollen grain flavonoids data of ten studied Brassicaceae taxa from the Shazand Thermal Power Plant area, Iran comparing to control using 2-DPC and TLC methods have been shown in Table 3. As the Table shows flavonoid sulfates and flavon $C$-and $C$ - $/ O$-glucosides were observed in all of studied control and polluted samples. Aglycones were not found in control and polluted samples of Alyssum longstylum, $G$. laevigata and $N$. apiculata species while both control and polluted samples of $A$. marginatum and $C$. lappacea species lacked. Polluted samples of C. persica, $D$. sophia and $C$. perfoliata had aglycones comparing to control but $I$. kotschyana and A. linifolium var. linifolium taxa control samples had aglycones in comparison with polluted. This study revealed high level changing in kind and number of pollen grain flavonoids between control and polluted samples. Flavonoids number increased in polluted samples comparing to control with the exception of $A$. marginatum and G. laevigata species. Polluted N. apiculata and $A$. marginatum showed the most increasing total flavonoids and $C$. lappacea was at least. Fourteen flavonoids compounds consisting of apigenin, chrysin, genistein, hesperidin, isorhamnetin, kaempferol, luteolin, morphine, myricetin, naringenin, quercetin, rhamnetin, rutin, tricine, and vitexin were found in control and polluted samples of studied taxa. Table 4 shows statistical analysis results of morphobiometrical, palynological and flavonoids studied data using SPSS by Tukey and Duncan tests. 
Table 1. Seed morphobiometrical data of 10 collected Brassicaceae taxa from the Shazand (Arak) Thermal Power Plant area, Iran comparing to control

\begin{tabular}{|c|c|c|c|c|c|c|c|c|c|c|c|c|}
\hline \multirow{3}{*}{ Taxa } & \multicolumn{2}{|c|}{ SLM (mm) } & \multirow{2}{*}{\multicolumn{2}{|c|}{$\begin{array}{c}\text { SWM (mm) } \\
\mathbf{M} \pm \text { SD }\end{array}$}} & \multirow{2}{*}{\multicolumn{2}{|c|}{ SDM (mm) }} & \multirow{2}{*}{\multicolumn{2}{|c|}{ SLM/SWM }} & \multirow{2}{*}{\multicolumn{2}{|c|}{ NS\% }} & \multirow{2}{*}{\multicolumn{2}{|c|}{ AS\% }} \\
\hline & & & & & & & & & & & & \\
\hline & C & $\mathbf{P}$ & $\mathbf{C}$ & $\mathbf{P}$ & $\mathbf{C}$ & $\mathbf{P}$ & C & $\mathbf{P}$ & C & $\mathbf{P}$ & $\mathbf{C}$ & $\mathbf{P}$ \\
\hline $\begin{array}{l}\text { Alyssum linifolium var. } \\
\text { linifolium }\end{array}$ & & $1.5 \pm 0.08$ & $0.97 \pm 0.07$ & $0.97 \pm 0.03$ & $0.22 \pm 0.01$ & $0.2 \pm 0.03$ & 1.65 & & 92 & 84 & 8 & 16 \\
\hline Alyssum longistylum & $2.14 \pm 0.01$ & $2.05 \pm 0.07$ & $1.51 \pm 0.07$ & $1.61 \pm 0.06$ & $066+004$ & $0.56 \pm 0.09$ & 1.42 & 1.27 & 97 & 94 & 3 & 6 \\
\hline & & & & & & & & & 99 & & 1 & 2 \\
\hline & & $2.56 \pm 0$. & $2 \pm 0.22$ & & & & & & 94 & & 6 & 19 \\
\hline Clyp & & $1.67 \pm 0.11$ & $7 \pm 0.06$ & & & & 1. & 1.13 & 94 & 6 & 6 & 33 \\
\hline a perfoliata & & $1.88 \pm 0.09$ & \pm 0.05 & & & & 1.9 & 2.35 & 97 & 90 & 3 & 10 \\
\hline Descurainia sophia & & & & & & & & & 95 & 8 & 5 & 11 \\
\hline Goldbachia laevigata & & & & & & & & & 80 & 75 & 20 & 25 \\
\hline & & & & & & & & & 87 & & 13 & 26 \\
\hline Neslia apiculata & $1.76 \pm 0.07$ & $1.60 \pm 0.09$ & $1.27 \pm 0.05$ & $1.12 \pm 0.12$ & $1.06 \pm 0.07$ & $0.87 \pm 0.12$ & 1.38 & 1.43 & 93 & 99 & 7 & 1 \\
\hline
\end{tabular}

Note: $\mathrm{C}=$ control, $\mathrm{P}=$ polluted, $\mathrm{SLM}=$ seed length max., $\mathrm{SWM}=$ seed width max., SLM/SWM=seed length max/seed width max., $\mathrm{SDM}=$ seed diameter max., NS\%= normal seed $\%, \mathrm{AS} \%=$ abnormal seed $\%$.

Table 2. Palynological data of polluted samples of 10 collected Brassicaceae from the Shazand Thermal Power Plant area, Iran comparing to control using Muntezing's acetocarmine method

\begin{tabular}{|c|c|c|c|c|c|c|c|c|c|c|c|c|c|c|c|c|}
\hline \multirow{3}{*}{ Taxa } & \multicolumn{6}{|c|}{ Normal pollen grain } & \multicolumn{6}{|c|}{ Abnormal pollen grain } & \multirow{2}{*}{\multicolumn{2}{|c|}{$\begin{array}{c}\text { Total fertility } \\
\%\end{array}$}} & \multirow{2}{*}{\multicolumn{2}{|c|}{$\begin{array}{c}\text { Total sterility } \\
\%\end{array}$}} \\
\hline & \multicolumn{2}{|c|}{$\begin{array}{c}\text { Normality } \\
\%\end{array}$} & \multicolumn{2}{|c|}{$\begin{array}{c}\text { Fertility } \\
\%\end{array}$} & \multicolumn{2}{|c|}{$\begin{array}{c}\text { Sterility } \\
\%\end{array}$} & \multicolumn{2}{|c|}{$\begin{array}{c}\text { Abnormality } \\
\%\end{array}$} & \multicolumn{2}{|c|}{$\begin{array}{c}\text { Fertility } \\
\%\end{array}$} & \multicolumn{2}{|c|}{$\begin{array}{c}\text { Sterility } \\
\%\end{array}$} & & & & \\
\hline & $\mathbf{C}$ & $\mathbf{P}$ & $\mathbf{C}$ & $\mathbf{P}$ & $\mathbf{C}$ & $\mathbf{P}$ & $\mathbf{C}$ & $\mathbf{P}$ & $\mathrm{C}$ & $\mathbf{P}$ & $\mathbf{C}$ & $\mathbf{P}$ & $\mathbf{C}$ & $\mathbf{P}$ & $\mathbf{C}$ & $\mathbf{P}$ \\
\hline $\begin{array}{l}\text { Alyssum linifolium var. } \\
\text { linifolium }\end{array}$ & 80.2 & 65.3 & 100 & 90.3 & 0 & 9.7 & 19.8 & 34.7 & 95 & 39.4 & 5 & 60.6 & 99 & 72.6 & 1 & 27.4 \\
\hline Alyssum longistylum & 71.8 & 53.6 & 98.2 & 96.6 & 1.8 & 3.4 & 28.2 & 46.4 & 81.8 & 69.2 & 18.2 & 30.8 & 93.6 & 66.07 & 6.4 & 33.93 \\
\hline Alysst & 89 & 50 & 100 & 91.6 & 0 & 8.4 & 11 & 50 & 80 & 75 & 20 & 25 & 97.8 & & & 16.67 \\
\hline spora persica & 79.1 & 69.9 & 100 & 100 & 0 & 0 & 20.9 & 30.1 & 80.5 & 30.6 & 19.5 & 69.4 & 95.9 & 79.1 & 4.1 & 20.9 \\
\hline Clypeola lappacea & 90.8 & 89.8 & 100 & 100 & 0 & 0 & 9.2 & 10.2 & 25 & 92.9 & 75 & 71 & 93.1 & 90.6 & 9 & 9.4 \\
\hline Conringia perfoliata & 97.9 & 87.4 & 100 & 100 & 0 & 0 & 2.1 & 12.6 & 0 & 34.8 & 100 & 65.2 & 97.9 & 91.8 & 1 & 8.2 \\
\hline & 98.2 & 75.4 & 100 & 100 & 0 & 0 & & 24.6 & 60 & 32.8 & 40 & 67 & & & & 16.5 \\
\hline igata & 96.4 & 95.1 & 100 & 99.1 & 0 & 0.9 & 3. & 4.9 & 75 & 16.7 & 25 & 83.3 & 99. & 95.08 & 0.91 & 4.92 \\
\hline & 95.3 & 49.2 & 100 & 93.8 & 0 & 6.2 & 4.7 & 50.8 & 0 & 16.4 & 100 & 83.6 & 95 & 54.5 & 4.7 & 45.5 \\
\hline Neslia apiculata & 85.3 & 83.8 & 98.9 & 98.5 & 1.1 & 1.5 & 14.7 & 16.2 & 43.7 & 46.2 & 56.3 & 53.8 & 90.82 & 90 & 9.18 & 10 \\
\hline
\end{tabular}

Note: $\mathrm{C}=$ control, $\mathrm{P}=$ polluted

Table 3. Pollen grain flavonoids data of ten studied Brassicaceae taxa from the Shazand Thermal Power Plant area, Iran comparing to control using 2-DPC and TLC methods

\begin{tabular}{|c|c|c|c|c|c|c|c|c|c|c|c|c|c|c|c|c|c|c|c|c|}
\hline \multirow{2}{*}{$\begin{array}{l}\text { Taxa } \\
\text { Characters }\end{array}$} & \multicolumn{2}{|c|}{ 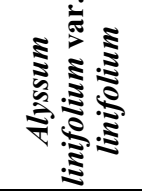 } & \multicolumn{2}{|c|}{ 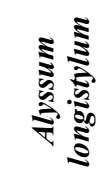 } & \multicolumn{2}{|c|}{ 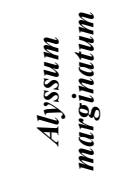 } & \multicolumn{2}{|c|}{ 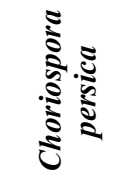 } & \multicolumn{2}{|c|}{ 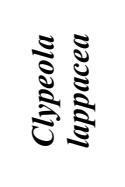 } & \multicolumn{2}{|c|}{ 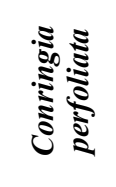 } & \multicolumn{2}{|c|}{ 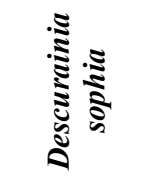 } & \multicolumn{2}{|c|}{ 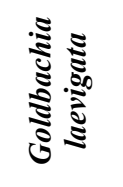 } & \multicolumn{2}{|c|}{ 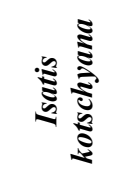 } & \multicolumn{2}{|c|}{ 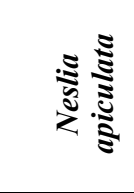 } \\
\hline & $\mathbf{C}$ & $\mathbf{P}$ & $\mathbf{C}$ & $\mathbf{P}$ & $\mathbf{C}$ & $\mathbf{P}$ & $\mathbf{C}$ & $\mathbf{P}$ & C & $\mathbf{P}$ & $\mathbf{C}$ & $\mathbf{P}$ & $\mathbf{C}$ & $\mathbf{P}$ & $\mathbf{C}$ & $\mathbf{P}$ & $\mathbf{C}$ & $\mathbf{P}$ & $\mathbf{C}$ & $\mathbf{P}$ \\
\hline Total flavonoids number & 6 & 10 & 7 & 9 & 5 & 4 & 8 & 11 & 10 & 11 & 9 & 12 & 6 & 8 & 11 & 7 & 9 & 11 & 7 & 11 \\
\hline Flavonoid sulphates number & 4 & 4 & 4 & 6 & 3 & 2 & 3 & 6 & 6 & 6 & 6 & 7 & 4 & 6 & 7 & 5 & 6 & 8 & 5 & 7 \\
\hline Flavon $C$-and $C$ - $/ O$-glucosides & 2 & 6 & 3 & 3 & 2 & 2 & 5 & 2 & 3 & 3 & 3 & 4 & 2 & 1 & 4 & 2 & 2 & 3 & 2 & 4 \\
\hline Aglycones & 1 & 0 & 0 & 0 & 1 & 1 & 0 & 3 & 1 & 2 & 0 & 1 & 0 & 1 & 0 & 0 & 1 & 0 & 0 & 0 \\
\hline Apigenin & - & - & - & - & - & - & ++ & +++ & ++ & +++ & + & ++ & +++ & ++ & - & - & ++ & - & - & - \\
\hline Chrysin & ++ & + & - & - & ++ & ++ & +++ & ++ & ++ & ++ & + & ++ & ++ & ++ & ++ & ++ & ++ & + & ++ & ++ \\
\hline Genistein & - & - & - & - & - & - & - & - & - & - & - & - & +++ & +++ & ++ & ++ & - & - & ++ & +++ \\
\hline Isorhamnetin & - & - & - & - & - & - & - & - & - & - & - & - & - & - & - & - & - & - & \pm & \pm \\
\hline Kaempferol & +++ & ++ & +++ & + & ++ & ++ & ++ & +++ & ++ & +++ & ++ & ++ & ++ & ++ & ++ & ++ & +++ & ++ & ++ & +++ \\
\hline Luteolin & - & - & - & - & ++ & ++ & + & + & ++ & ++ & + & + & ++ & ++ & - & - & - & - & ++ & ++ \\
\hline Morin & - & - & - & - & - & - & - & - & - & ++ & - & - & - & - & - & - & - & - & - & - \\
\hline Myricetin & + & + & - & - & - & - & - & - & - & ++ & - & + & +++ & ++ & ++ & ++ & ++ & - & - & - \\
\hline Naringenin & - & - & - & - & - & - & - & - & ++ & +++ & - & - & ++ & ++ & ++ & ++ & ++ & - & \pm & + \\
\hline Quercetin & +++ & +++ & +++ & + & +++ & ++ & ++ & +++ & ++ & +++ & ++ & ++ & +++ & ++ & ++ & ++ & ++ & ++ & ++ & ++ \\
\hline Rhamnetin & - & - & \pm & - & - & - & - & - & - & - & - & - & - & - & - & - & - & - & \pm & \pm \\
\hline Rutin & - & - & - & - & - & - & ++ & ++ & - & - & - & - & - & - & ++ & ++ & - & - & - & - \\
\hline Tricin & - & - & \pm & + & - & - & - & - & - & - & - & - & - & - & - & - & - & - & - & - \\
\hline Vitexin & - & - & - & - & ++ & ++ & - & - & \pm & \pm & - & - & + & + & - & - & ++ & ++ & - & - \\
\hline
\end{tabular}

Note: Scored characters: - (non flavonoid $=1), \pm(\mathrm{UV}$ absorbance $<0.1$, rare concentration of flavonoid=2), $+($ few concentration of flavonoid $=3),++($ middle concentration of flavonoid $=4),+++($ high concentration of flavonoid=5) 
Also Table 5 shows selected significant parameters by ANOVA $(P \leq 0.05)$.

\section{Discussion}

As Table 1 shows pollution have affected on seed dimensions in all of studied polluted samples. Seed dimensions have reduced in polluted plants comparing to control. But seed width has been exceptionally increased in Alyssum longstylum and Descurainia sophia. All of polluted sample fruits had more abnormal seeds number (without kernel, holed or wrinkled) in comparison with control (Figure 3). G. laevigata and N. apiculata polluted fruits had less abnormal seeds than control. Statistical analysis results in Tukey and Duncan tests showed that power plant pollutant had been caused normal seed number reduction in all of species exceptional $G$. laevigata and $N$. apiculata that confirmed Agrawal and Deepak (2003). $\mathrm{SO}_{2}$ effects on soybean caused seed number reduction and consequently crop decreasing. Sprugel et al. (1980) showed using 0.09-0.79 $\mu \mathrm{g} / \mathrm{Lit} \mathrm{SO}_{2}$ on soybean significantly caused seed weight and number reduction that mainly reduced crop (Sprugel et al. 1980; Reich and Amundson 1984).

Using Muntezing's acetocarmine pollen grain staining method revealed decreasing of fertility in all of ten studied polluted Brassicaceae taxa (Table 2). The method is one of the most widely used staining techniques for pollen viability estimation and shows sharp differences in smearing advanced pollen grains from abnormal ones. As a result, sharply stained pollen grains were considered as potential of fertile and viable ones, and partially stained, no stained, or weakly stained pollen grains were considered nonviable and sterile (Malayeri et al. 2011). As Table 2 shows the highest abnormality and sterility percentages pollen grain was observed in I. kotschyana in comparison with the same species control samples and also other polluted species. The results show stimulation and inhibition of these pollen characteristics depend on the plant species as well as on the pollutant and its concentration. Finally, this study indicates that air pollution can induce several abnormality and sterility in plant pollen grains.
Table 4. Statistical analysis results of seed and pollen morphobiometrical and pollen flavonoids data using SPSS by Tukey and Duncan tests $(P \leq 0.05)$

\begin{tabular}{|c|c|c|c|c|}
\hline $\begin{array}{l}\text { Test of homogeneity of } \\
\text { variances }\end{array}$ & $\begin{array}{l}\text { Levene } \\
\text { statistic }\end{array}$ & DF & DF2 & SIG. \\
\hline Apigenin & .375 & 1 & 18 & .548 \\
\hline Chrysin & .000 & 1 & 18 & 1.000 \\
\hline Genistin & .000 & 1 & 18 & 1.000 \\
\hline Isorhamnetin & .000 & 1 & 18 & 1.000 \\
\hline Luteolin & .000 & 1 & 18 & 1.000 \\
\hline Morin & 5.062 & 1 & 18 & $* .037$ \\
\hline Myricetin & .375 & 1 & 18 & .548 \\
\hline Naringenin & .375 & 1 & 18 & .548 \\
\hline Rhamnetin & .050 & 1 & 18 & .826 \\
\hline Rutin & .000 & 1 & 18 & 1.000 \\
\hline Tricin & 1.013 & 1 & 18 & .328 \\
\hline Vitexin & .000 & 1 & 18 & 1.000 \\
\hline Flavonoid Sulphates Number & .002 & 1 & 18 & .961 \\
\hline Aglycones Number & 2.796 & 1 & 18 & .112 \\
\hline $\begin{array}{l}\text { Flavonoid C-and } \quad \text { C-/O- } \\
\text { glucosides Number }\end{array}$ & .321 & 1 & 18 & .578 \\
\hline Total Flavonoid Number & .361 & 1 & 18 & .555 \\
\hline Apigenin concentration & .698 & 1 & 18 & .414 \\
\hline Chrysin concentration & .004 & 1 & 18 & .950 \\
\hline Genistin concentration & .184 & 1 & 18 & .673 \\
\hline Isorhamnetin concentration & .000 & 1 & 18 & 1.000 \\
\hline Kaempferol concentration & 5.684 & 1 & 18 & $* .028$ \\
\hline Luteolin concentration & .000 & 1 & 18 & 1.000 \\
\hline Morin concentration & 5.062 & 1 & 18 & $* .037$ \\
\hline Myricetin concentration & .434 & 1 & 18 & .518 \\
\hline Naringenin concentration & .129 & 1 & 18 & .724 \\
\hline Quercetin concentration & .000 & 1 & 18 & 1.000 \\
\hline Rhamnetin concentration & 1.531 & 1 & 18 & .232 \\
\hline Rutin concentration & .000 & 1 & 18 & 1.000 \\
\hline Tricin concentration & 1.013 & 1 & 18 & .328 \\
\hline Vitexin concentration & .000 & 1 & 18 & 1.000 \\
\hline Seed length max. & .026 & 1 & 18 & .874 \\
\hline Seed width max. & .000 & 1 & 18 & .996 \\
\hline Seed length max/Seed width max. & .112 & 1 & 18 & .742 \\
\hline Seed diameter max. & .172 & 1 & 18 & .684 \\
\hline Abnormal seed percentage & 5.878 & 1 & 18 & $* .026$ \\
\hline Abnormal pollen percentage & 5.653 & 1 & 18 & $* .029$ \\
\hline Sterile pollen percentage & 10.464 & 1 & 18 & $* .005$ \\
\hline
\end{tabular}

Note: *Bold numbers significant $(P \leq 0.05)$

Table 5. Selected seed and pollen morphobiometrical and pollen flavonoids significant parameters by ANOVA $(P \leq 0.05)$

\begin{tabular}{|c|c|c|c|c|c|c|}
\hline ANOVA & & Sum of Squares & df & Mean square & $\mathbf{F}$ & Sig \\
\hline \multirow[t]{3}{*}{ Kaempferol concentration } & Between Groups & .800 & 1 & .800 & 4.800 & ${ }^{*} .042$. \\
\hline & Within Groups & 3.000 & 18 & .167 & & \\
\hline & Total & 3.800 & 19 & & & \\
\hline \multirow[t]{3}{*}{ Abnormal seed \% } & Between Groups & 296.450 & 1 & 296.450 & 4.017 & .060 \\
\hline & Within Groups & 1328.500 & 18 & 73.806 & & \\
\hline & Total & 1624.950 & 19 & & & \\
\hline \multirow[t]{3}{*}{ Abnrormal pollen grain $\%$} & Between Groups & 1353.013 & 1 & 1353.013 & 7.220 & $* .015$ \\
\hline & Within Groups & 3373.005 & 18 & 187.389 & & \\
\hline & Total & 4726.018 & 19 & & & \\
\hline \multirow[t]{3}{*}{ Sterile pollen $\%$} & Between Groups & 1204.818 & 1 & 1204.818 & 13.766 & $* .002$ \\
\hline & Within Groups & 1575.343 & 18 & 87.519 & & \\
\hline & Total & 2780.161 & 19 & & & \\
\hline
\end{tabular}




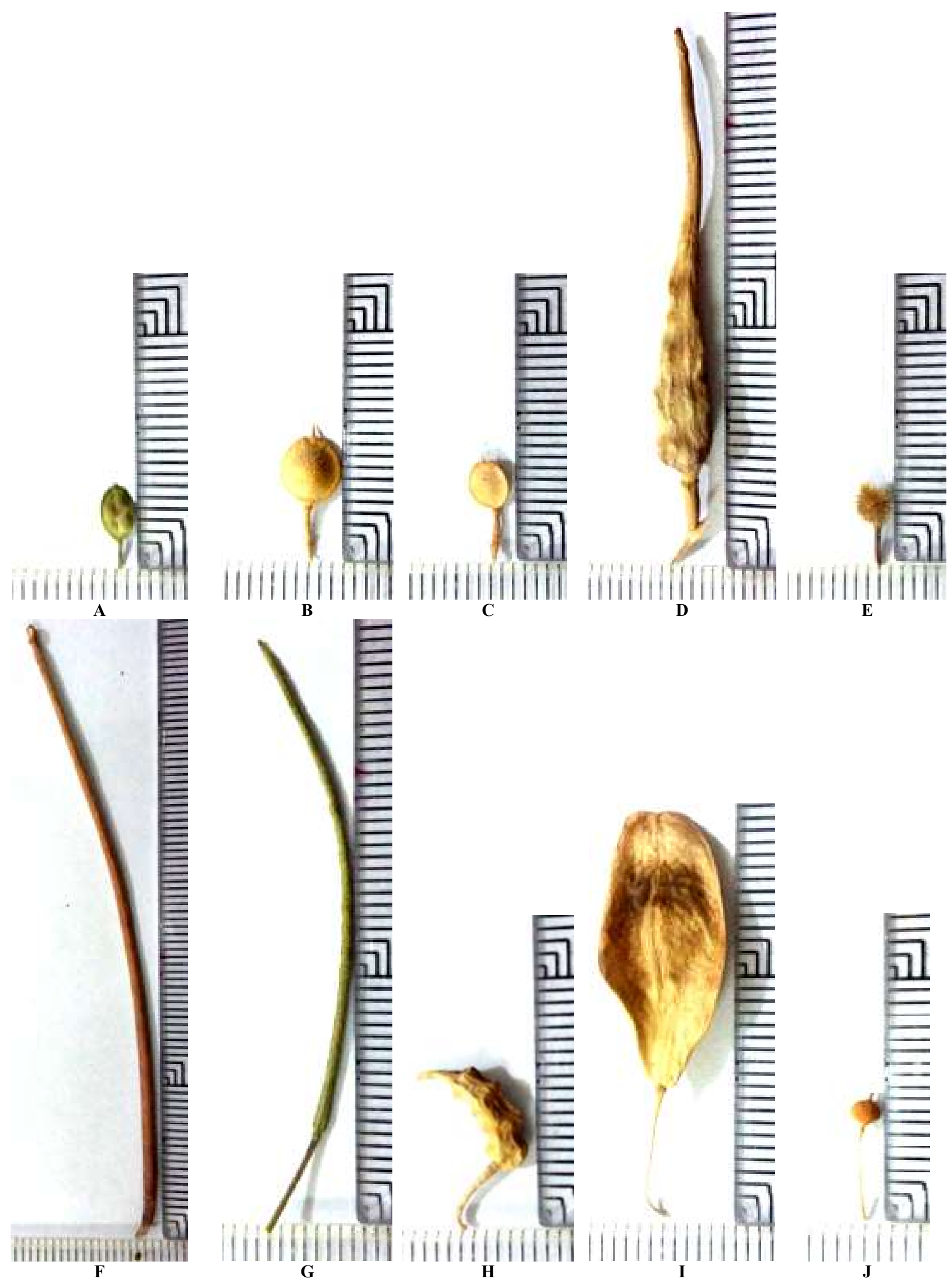

Figure 3. Showing fruits of 10 studied Brassicaceae taxa. A. Alyssum linifolium var. linifolium, B. Alyssum longstylum, C. Alyssum marginatum, D. Choriospora persica, E. Clypeola lappacea, F. Conringia perfoliata, G. Descurainia sophia, H. Goldbachia laevigata, I. Isatis kotschyana, J. Neslia apiculata. Strip $=1 \mathrm{~mm}$ 
Phytochemical results in Table 3 show many changes in kind and number of flavonoids in polluted plants compared to control. The total flavonoids increasing were observed in polluted samples of $N$. apiculata and A. linifolium. Flavonoids number increase in polluted Robinia pseudoacacia grown under fluoride pollutant (Noori et al. 2009). Also using HPLC method on polluted pollen grain ethanolic extracts of Lagerstroemia speciosa, Spartium junceum, Petunia hybrid and Thuja orientalis showed that air pollution caused high-level flavonoids accumulation in polluted samples in comparison with control (Rezanezhad 2012). Flavonoid sulfates number in A. longistylum, $C$. persica, C. perfoliata, D. sophia, I. kotschyana and $N$. apiculata polluted pollen grains were more than control while these flavonoids in A. marginatum and G. laevigata were less than and $A$. linifolium and $C$. lappacea did not show any changes. As our TLC results show, some flavonoids appeared in polluted samples while disappearance others were observed. Quercetin and kaempferol were found in all of control and polluted samples while rhamnetin lacked. Tricin was just found in polluted A. longistylum sample. Chrysin found in all of control and polluted samples except A. longistylum. Presence of morin and myricetin in polluted $C$. perfoliata and I. kotschyana and absence in their control show creation or deletion of flavonoids under pollutant effects. Studies on eight angiosperm plants collected from Shazand Oil Refinery area, Iran using two-dimensional paper and thin layer chromatography showed flavonoids kind and number changing in polluted plants comparing to control. Also, kaempferol appearance in polluted Amaranthus chlorostachys samples comparing to control was observed (Kamalabadi 2013).

Robles et al. (2003) studied phenols and flavonoids in Aleppo pine needles as bioindicators of air pollution. Their results showed that total flavonoids are useful bioindicators for ozone pollution (significant positive correlations between total flavonols and ozone pollution). Sulfur dioxide pollution is distinguished by low concentrations in quercetin, isorhamnetin, and kaempferol (significant negative correlations between these simple flavonols and the concentrations of SO2).) The work confirms strong interest of using the phenolic compounds of Pinus halepensis as biological indicators of air quality (Robles et al. 2003). Rubin et al. (1983) found induction of isoflavonoid production in Phaseolus vulgaris leaves by ozone, sulfur dioxide and herbicide stress (Rubin et al. 1983). Total flavonoids reduction was observed in treated plants with heat and $\mathrm{SO}_{2}$ (Lee et al. 2002; Lavola, 1997). Increasing total flavonoids and phenolic compounds were observed in collected Catharanthus roseus and Ocimum sanctum from $\mathrm{NO}_{2}$ and $\mathrm{SO}_{2}$ polluted area. These plants can be used as bioindicators (Qayoom et al, 2009). Increasing or reduction of flavonoids under air pollutant can show pollution effects on flavonoids. Phytochemical changes in aluminum smelter industry area vegetation were observed with appearance or disappearance of flavonoids in fluoride polluted plants (Noori et al. 2009). Statistical analysis results of morphobiometrical and flavonoids data using
SPSS by Tukey and Duncan tests in Table 4 show morin existence and morin and kaempferol concentrations, abnormal seed and pollen percentages and sterile pollen $\%$ are significant $(P \leq 0.05)$. Also, Table 5 shows selected seed morphobiometrical, palynological and pollen phytochemicals significant parameters by ANOVA method $(P \leq 0.05)$ and confirms that kaempferol concentration, abnormal seed and pollen grains percentages and sterile pollen $\%$ are three significant parameters. These results have coincided on Sprugel et al. (1980) about seeds, Noori et al. (2014) about pollen and Kamalabadi (2013) about flavonoids. It is known that plant flavonoids pattern depends on genetics factors and ecological conditions.

Results of the study confirmed that pollen grains provide essential information on biological impact of pollutants and they are good candidates for biomonitoring the atmospheric and edaphic pollutions. As Ruffin et al. (1983) studied effects of some environmental gaseous pollutants on pollen-wall proteins of certain airborne pollen grains. They used pure pollen grains of Ulmus pumila, Quercus rubra, Pinus taeda, and Festuca elatior were used as a biological screen to test the effects of certain commonly occurring atmospheric pollutants on pollen wall protein (Ruffin et al. 1983). Also, Rezanejad (2009) studied air pollution effects on structure, proteins, and flavonoids in pollen grains of Thuja orientalis.

Pollutions such as power plant pollutant are caused by different environmental effects. The most pollutants of power plant are $\mathrm{SO}_{2}, \mathrm{NO}, \mathrm{NO}_{2}, \mathrm{CO}$, and $\mathrm{CO}_{2}$ that affected on ecosystem and plant vegetation. These atmospheric pollutants affect pollen morphobiometry, fertility, and phytochemistry. Their effective on plants caused different morphological, physiological and phytochemical responses to pollutants that reduced pollen and seed production and their viability and fertility. Changes in flavonoids kind and number especially flavonoids sulfates production or increasing in polluted plant in comparison with control plant defensive reactions to pollutants. It seems that environmental pollution reduced plant resistance against catching disease and pest attack and increased plant sterility. Then studying pollen characters such as viability, morphobiometery, their phenols and flavonoids compounds and also seed production and characters can be used as air quality bioindicators.

\section{ACKNOWLEDGEMENTS}

The authors would like to thank of Mrs. and Mr. Faraki for their help in collecting of our samples.

\section{REFERENCES}

Agrawal M, Deepak SS. 2003. Physiological and biochemical responses of two cultivars of wheat to elevated levels of $\mathrm{CO}_{2}$ and $\mathrm{SO}_{2}$, singly and in combination. Environ Pollut 121: 189-197.

Bosac C, Roberts JA, Black VJ, Black CR. 1994. Impact of $\mathrm{O}_{3}$ and $\mathrm{SO}_{2}$ on reproductive development in oilseed rape (Brassica napus L.). II. Reproductive site losses. New Phytol 126 (1): 71-79. 
Chalker-Scott L. 1999. Environmental significance of anthocyanins in plant stress responses. Photochem Photobiol 70: 1-9.

Chehregani A, Kouhkan F. 2008. Diesel exhaust particles and allergenicity of pollen grains of Lilium martagon. Iran Ecotoxic Environ Safe 69: 568-573.

Chehregani A, Malayeri EB, Kavianpour F, Lari Yazdi H. 2006. Effect of acid Rain on the development, structure and viability of pollen grains. Pakistan J Biol Sci 9: 1033-1036.

Elke K. 1990. Reduced fertilization capacity of $\mathrm{SO}_{2}$-fumigated Picea omorika-pollen. Eur J ForPathol 20: 122-126.

Feucht W, Treutter D. 1999. The Role of Flavan-3-ols and Proanthocyanidins in Plant Defence. In: Inderjit S, Dakshini KMM, Foy CL (eds.). Principles and Practices in Chemical Ecology. CRC Press, Boca Raton, CA.

Ghahreman A. 1980-2002. Color flora of Iran, Research Institute of Forest and Rangelands, Tehran, Iran. Volumes 1-24. RIFR, Ministry of Reconstruction Jahad, Iran.

Gottardini E, Cristofolini F, Paoletti E, Lazzeri P, Pepponi G. 2004. Pollen viability for air pollution bio-monitoring. J Atmos Chem 49: 149-159.

Harborne JB. 1998. Phytochemistry Methods. 3rd ed. Chapman and Hall, London.

ILDIS [International Legume Database and Information Service] and CHCD [Chapman and Hall Chemical Database]. 1994. Plants and their constituents. In: Bis FA (ed.). Phytochemical dictionary of the Leguminosae. Chapman and Hall, New York.

Kamalabadi FM. 2013. Comparison of Leaf Anatomical, Palynologica and Phytochemical Characters in Collected Wild Plants from Shazand Oil Refinery Area and Control. [Thesis]. Arak University, Iran. [Persian]

Lee J, Durst RW, Wrolstad RE. 2002. Impact of juice processing on blueberry anthocyanins and polyphenolics: comparison of two pretreatments. J Food Sci 67: 1660.

Mabry TJ, Markhm KR, Thomas MB. 1970. The Systematic Identification of Flavonoids. Springer Verlag, Berlin.

Majd A, Chehregani A, Moin M, Gholami M, Kohno S, Nabe T, Shariatzadeh MA. 2004. The effects of air pollution on structure, proteins and allergenicity of pollen grains. Aerobiol 20: 111-118.

Malayeri BE., Chehregani A, Yosefi N, Lorestani B. 2007. Identification of the hyper accumulator plants in copper and iron mine in Iran Pakistan J Biol Sci 11: 490-492.

Malayeri BE, Noori M, Jafari M. 2011. Using the pollen viability and morphology for fluoride pollution biomonitoring. Biol Trace Element Res. DOI: 10.1007/s12011-011-9290-8.

Markham KR. 1982. Techniques of Flavonoid Identification. Academic Press, London.
Mobayen S. 1985. Flora of Iran, Vascular plants 2. Tehran University Press, Tehran

Noori M. 2002. Characterization of the Iranian Species of Sophora and Ammodendron (Leguminosae; Sophoreae). [Dissertation]. University of London and Royal Botanic Gardens, Kew, UK.

Noori M, Bakhshi-Khaniki GR, Aghabagheri F. 2014. Morphobiometrical studies of pollen grain in collected legumes from Shazan Thermal Power Plant area-Iran. Intl J Ecosys 4: 19-23.

Noori M, Malayeri BE., Jafari M. 2009. Determination of fluoride and its effects on flavonoids in some legumes. Toxicol Environ Chem 91: 409-418.

Qayoom Mir A, Yazdani T, Ahmad S, Yunus M. 2009. Total flavonoids and phenolics in Catharanthus roseus L. and Ocimum sanctum L. as biomarkers of urban auto pollution Caspian. J Environ Sci 7: 9-16.

Rechinger KH. 1968. "Crucifreae", In: K. H. Rechinger (ed.). Flora Iranica 157. Akademische-v, (1968), No. 57/28. 2019 , Verlagsantalt, Graz, Austria.

Reich PB, Amundson RG. 1984. Low level $\mathrm{O}_{3}$ and/or $\mathrm{SO}_{2}$ exposure causes a linear decline in soybean yield. Environ Pollut 34: 345-355.

Rezanejad F. 2012. Air pollution effects on flavonoids in pollen grains of some ornamental plants. Turk J Bot 36: 49-54.

Rezanezhad F, Nasibi F. 2006. Effect of air pollution on flavonoids level in Spartium junceum and Lagerstroemia indica, $14^{\text {th }}$ International Biology Congress in Iran, Tarbiat Modares University, 29-31 August 2006, Tehran-Iran. [Persian]

Robles, C, Greff S, Pasqualini V, Garzino S, Bousquet-Melou A, Fernandez C, Korboulewsky N, Bonin G. 2003. Phenols and flavonoids in Aleppo pine needles as bioindicators of air pollutionPlant and environment interaction. J Environ Qual 32: 2265-2271.

Rubin B, Penner D, Saettler AW. 1983. Induction of isoflavonoid production in Phaseolus vulgaris L. leaves by ozone, sulfur dioxide and herbicide stress. Environ Toxicol Chem 295-306.

Ruffin J, Liu MY, Sessoms R, Banerjee S, Banerjee UC. 1986. Effects of certain atmospheric pollutants $\left(\mathrm{SO}_{2}, \mathrm{NO}_{2}\right.$ and $\left.\mathrm{CO}\right)$ on the soluble amino acids, molecular weight and antigenicity of some airborne pollen grains. Cytobios 46: 119-129.

Ruffin J, Williams D, Banerjee U, Pinnix K. 1983. The effects of some environmental gaseous pollutants on pollen-wall proteins of certain airborne pollen grains: a preliminary study. Grana 22: 171-175.

Sprugel DG, Miller JE, Muller RN, Smith HJ, Xerikos PB. 1980, Sulfur dioxid effects on yield and seed quality in field-grown soybeans. Phytopathology 70: 1129-1133.

Yosefi N, Chehregani A, Malayeri BE, Lorestani B, Cheraghi M. 2011. Investigating the effect of heavy metals on developmental stages of anther and pollen in Chenopodium botrys L. (Chenopodiaceae). Biol Trace Element Res 140: 368-3766. 